Relative Distribution and Abundance of Fishes and Crayfish in 2010 and 2014 Prior to Saltcedar (Tamarix ssp.) Removal in the Amargosa River Canyon, Southeastern California

Open-File Report 2016-1112 



\section{Relative Distribution and Abundance of Fishes and}

Crayfish in 2010 and 2014 Prior to Saltcedar (Tamarix ssp.) Removal in the Amargosa River Canyon, Southeastern California

By Mark E. Hereford

Open-File Report 2016-1112 


\section{U.S. Department of the Interior \\ SALLY JEWELL, Secretary}

\section{U.S. Geological Survey \\ Suzette M. Kimball, Director}

U.S. Geological Survey, Reston, Virginia: 2016

For more information on the USGS—-the Federal source for science about the Earth,

its natural and living resources, natural hazards, and the environment-visit

http://www.usgs.gov/ or call 1-888-ASK-USGS (1-888-275-8747).

For an overview of USGS information products, including maps, imagery, and publications, visit http://store.usgs.gov.

Any use of trade, firm, or product names is for descriptive purposes only and does not imply endorsement by the U.S. Government.

Although this information product, for the most part, is in the public domain, it also may contain copyrighted materials as noted in the text. Permission to reproduce copyrighted items must be secured from the copyright owner.

Suggested citation:

Hereford, M.E., 2016, Relative distribution and abundance of fishes and crayfish in 2010 and 2014 prior to saltcedar (Tamarix ssp.) removal in the Amargosa River Canyon, southeastern California: U.S. Geological Survey Open-File Report 2016-1112, 18 p., http://dx.doi.org/10.3133/ofr20161112.

ISSN 2331-1258 (online) 


\section{Contents}

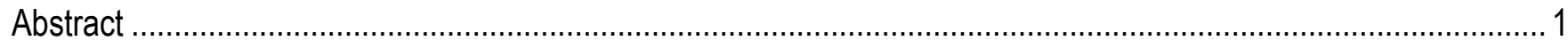

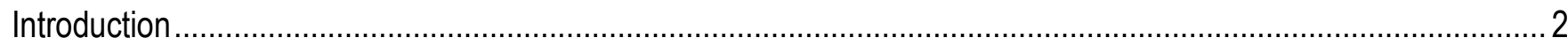

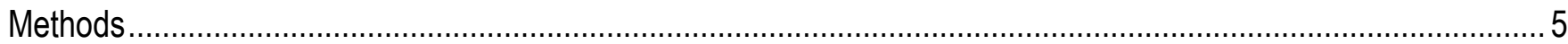

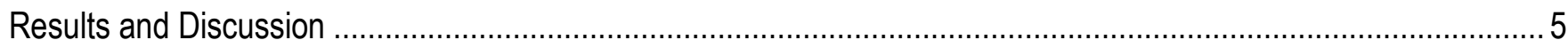

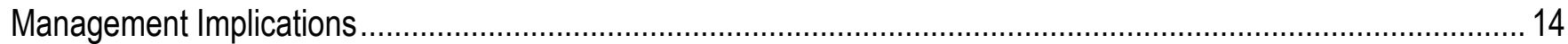

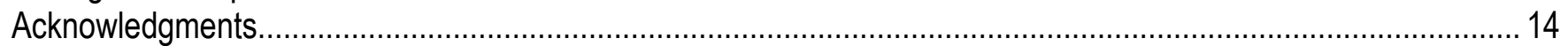

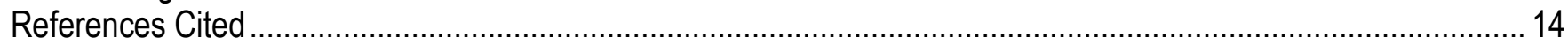

Appendix A. Dominant Vegetation Type, Vegetation Percentage of Cover (2014 only), and Stream Characteristics (2014 only) from the 2010 and 2014 Fish and Crayfish Surveys of the Treatment Reach in the Amargosa River,

California.

\section{Figures}

Figure 1. Map depicting the location of the surveyed treatment reach located on the Amargosa River within the Bureau of Land Management Area of Critical Environmental Concern (ACEC) in California.

Figure 2. Length histograms of Amargosa River pupfish (Cyprinodon nevadensis amargosae) captured in the treatment reach of the Amargosa River, California during the 2010 and 2014 surveys

Figure 3. Length histograms of speckled dace (Rhinichthys osculus spp.) captured in the treatment reach of the Amargosa River, California during the 2010 and 2014 surveys

Figure 4. Relative distribution and abundance of Amargosa River pupfish (Cyprinodon nevadensis amargosae) along the treatment reach of the Amargosa River, California surveyed in 2010 and 2014

Figure 5. Relative distribution and abundance of speckled dace (Rhinichthys osculus spp.) along the treatment reach of the Amargosa River, California surveyed in 2010 and 2014

Figure 6. Relative distribution and abundance of western mosquitofish (Gambusia affins) along the treatment reach of the Amargosa River, California surveyed in 2010 and 2014

Figure 7. Relative distribution and abundance of red swamp crayfish (Procambarus clarkii) along the treatment reach of the Amargosa River, California surveyed in 2010 and 2014

Figure 8. Dominant riparian vegetation present at sample sites during the 2010 and 2014 fish and crayfish surveys along the treatment reach of the Amargosa River, California. Each dot represents an individual trap location

\section{Table}

Table 1. Total captures and catch per unit effort (CPUE) of fishes and crayfish in the treatment reach of the Amargosa River Canyon, California surveyed in 2010 and 2014. 


\section{Conversions Factors}

Inch/Pound to International System of Units

\begin{tabular}{lcl}
\hline \multicolumn{1}{c}{ Multiply } & By & \multicolumn{1}{c}{ To obtain } \\
\hline acre & Area & \\
\hline & 0.40470 & hectare (ha) \\
\hline cubic foot per second $\left(\mathrm{ft}^{3} / \mathrm{s}\right)$ & 0.02832 & cubic meter per second $\left(\mathrm{m}^{3} / \mathrm{s}\right)$ \\
\hline & Length & \\
\hline millimeter $(\mathrm{mm})$ & 0.03937 & inch $($ in. $)$ \\
\hline meter $(\mathrm{m})$ & 3.28 & foot \\
\hline kilometer $(\mathrm{km})$ & 0.621 & mile \\
\hline
\end{tabular}

Temperature in degrees Celsius $\left({ }^{\circ} \mathrm{C}\right)$ may be converted to degrees Fahrenheit $\left({ }^{\circ} \mathrm{F}\right)$ as ${ }^{\circ} \mathrm{F}=\left(1.8 \times{ }^{\circ} \mathrm{C}\right)+32$.

\section{Datum}

Horizontal coordinate information is referenced to the North American Datum of 1983 (NAD 83). 


\title{
Relative Distribution and Abundance of Fishes and Crayfish in 2010 and 2014 Prior to Removal of Saltcedar (Tamarix ssp.) in the Amargosa River Canyon, Southeastern California
}

By Mark E. Hereford

\begin{abstract}
The Amargosa River Canyon, located in the Mojave Desert of southeastern California, contains the longest perennial reach of the Amargosa River. Because of its diverse flora and fauna, it has been designated as an Area of Critical Environmental Concern and a Wild and Scenic River by the Bureau of Land Management. A survey of fishes conducted in summer 2010 indicated that endemic Amargosa River pupfish (Cyprinodon nevadensis amargosae) and speckled dace (Rhinichthys osculus spp.) were abundant and occurred throughout the Amargosa River Canyon. The 2010 survey reported non-native red swamp crayfish (Procambarus clarkii) and western mosquitofish (Gambusia affinis) captures were significantly higher, whereas pupfish captures were lower, in areas dominated by non-native saltcedar (Tamarix ssp.). Based on the 2010 survey, it was hypothesized that the invasion of saltcedar could result in a decrease in native species. In an effort to maintain and enhance native fish populations, the Bureau of Land Management removed saltcedar from a 1,550 meter reach of stream on the Amargosa River in autumn 2014 and autumn 2015. Prior to the removal of saltcedar, a survey of fishes and crayfish using baited minnow traps was conducted in the treatment reach to serve as a baseline for future comparisons with post-saltcedar removal surveys. During the 2014 survey, 1,073 pupfish and 960 speckled dace were captured within the treatment reach. Catch per unit effort of pupfish and speckled dace in the treatment reach was less in 2014 than in 2010, although differences could be owing to seasonal variation in capture probability. Non-native mosquitofish catch per unit effort decreased from 2010 to 2014; however, the catch per unit effort of crayfish increased from 2010 to 2014. Future monitoring efforts of this reach should be conducted at the same time period to account for potential seasonal fluctuations of abundance and distribution of fishes and crayfish. A more robust study design that accounts for variation in capture probability could be implemented to quantify the effects of habitat modifications on abundance of fishes and crayfish.
\end{abstract}




\section{Introduction}

Almost one-half of the described vertebrate species on Earth are fishes, 700 of which are found in the freshwater ecosystems of North America (Allan and Flecker, 1993). Geologic and biologic processes have influenced this diversity. Geologic processes can isolate hydrologic drainages, isolating fish populations from each other, resulting in genetic dissimilarity between populations and different evolutionary trajectories. This has resulted in an extraordinary amount of diversity of different species and subspecies of fishes (Allan and Flecker, 1993). However, freshwater fishes and their ecosystems are among the most threatened fishes and ecosystems in the World (Ward, 1998; Malmqvist and Rundle, 2002; Dudgeon and others, 2006). There are many causes for the decrease in biodiversity of freshwater fishes, including habitat loss and degradation, invasive species, overexploitation, secondary extinctions, chemical and organic pollution, and climate change (Allan and Flecker, 1993).

One of the major threats to endemic biodiversity of aquatic ecosystems is the invasion of nonnative species (Dudgeon and others, 2006). Non-native saltcedar (Tamarix spp.) has proliferated throughout aquatic habitats in the Southwestern United States since its cultivation in the early 1900s (Di Tomaso, 1998). Saltcedar can change the dynamics of aquatic ecosystems by lowering the groundwater table, altering organic matter inputs, decreasing the amount of sunlight available, and reducing algae abundance for aquatic herbivores (Kennedy and Hobbie, 2004; Kennedy and others, 2005). Invasions of non-native western mosquitofish (Gambusia affinis), and red swamp crayfish (Procambarus clarkii) also pose a major threat to the biodiversity of these unique ecosystems through competition and predation on native fishes (Guan and Wiles, 1997; Caiola and de Sostoa, 2005). Removal of saltcedar from aquatic ecosystems is a popular management strategy that has a positive effect on the abundance of native fishes while also decreasing non-native crayfish, and is a high priority in managing aquatic ecosystems throughout the arid Southwest (Kennedy and others, 2005; Shafroth and others, 2005).

The Amargosa River is an ephemeral stream in the Mojave Desert of southeastern California. During the late Pleistocene epoch, it traveled its entire course from southeastern Nevada to what is now known as the Badwaters of Death Valley, California (Hubbs and Miller, 1948). Perennial aquatic habitat is located where springs and seeps separate long stretches of arid desert. This unique combination of arid desert dotted with areas of surface water containing perennial riparian vegetation has allowed for a diverse set of aquatic biota, most of which are endemic. Endemic aquatic biota of the Amargosa River watershed include the Devils Hole pupfish, eight other subspecies of pupfish, speckled dace, spring snails, aquatic beetles, and the very rare Amargosa toad (Anaxyrus nelsoni; Williams and others, 1984; Deacon and Deacon-Williams, 1991). Within the Amargosa River watershed, the Amargosa River pupfish (Cyprinodon nevadensis amargosae) and speckled dace (Rhinichthys osculus spp.) are two fishes endemic to the Amargosa River Canyon. 
The Amargosa River Canyon contains the longest perennial reach of the Amargosa River and is located in Inyo and San Bernardino Counties, California. Because of the biological importance, historical and cultural values, and scenic beauty of the Amargosa River, the Bureau of Land Management (hereinafter, BLM) designated 21,552 acres surrounding the river as an Area of Critical Environmental Concern (Bureau of Land Management, 2006). Segments of the Amargosa River were designated by Congress as Wild and Scenic under provisions of the Omnibus Public Lands Management Act of 2009 (Public Law 111-11). In summer 2010, a survey was conducted to determine the relative distribution and abundance of Amargosa River pupfish (hereinafter, pupfish) and speckled dace throughout the entire 16.75-km perennial reach of the Amargosa River Canyon (Scoppettone and others, 2011). During the 2010 survey, it was noted that saltcedar had invaded a large part of the Amargosa River Canyon. In 2010, pupfish $(n=8,558)$ and speckled dace $(n=3,429)$ were distributed throughout the stream in relatively large numbers. However, pupfish captures were substantially less in stream reaches dominated by saltcedar. Red swamp crayfish $(\mathrm{n}=195)$ and mosquitofish $(\mathrm{n}=1,095)$ were relatively rare but widespread in distribution, and likely pose a threat to native fishes (Scoppettone and others, 2011).

In October 2014, a second survey of fishes and crayfish was conducted in the Amargosa River Canyon prior to saltcedar removal. Saltcedar was removed in autumn 2014 and autumn 2015 along a stream reach (hereinafter, treatment reach) 1.5 river kilometers south of the Old Spanish Trail Highway and $1,550 \mathrm{~m}$ in length (fig. 1). To facilitate comparison of relative distribution and abundance of fishes and crayfish and provide a pre-treatment baseline for saltcedar removal, sampling locations for the fish and crayfish survey in 2014 were identical to locations in 2010 in the treatment reach, with the exception of a 500-m reach where traps were set at a greater density.

The objectives of this study are to (1) compare the relative abundance and distribution of pupfish, speckled dace, mosquitofish, and crayfish in 2010 and 2014 in the treatment reach, and (2) describe the relative abundance and distribution of these species and the surrounding riparian vegetation prior to the removal of saltcedar. 


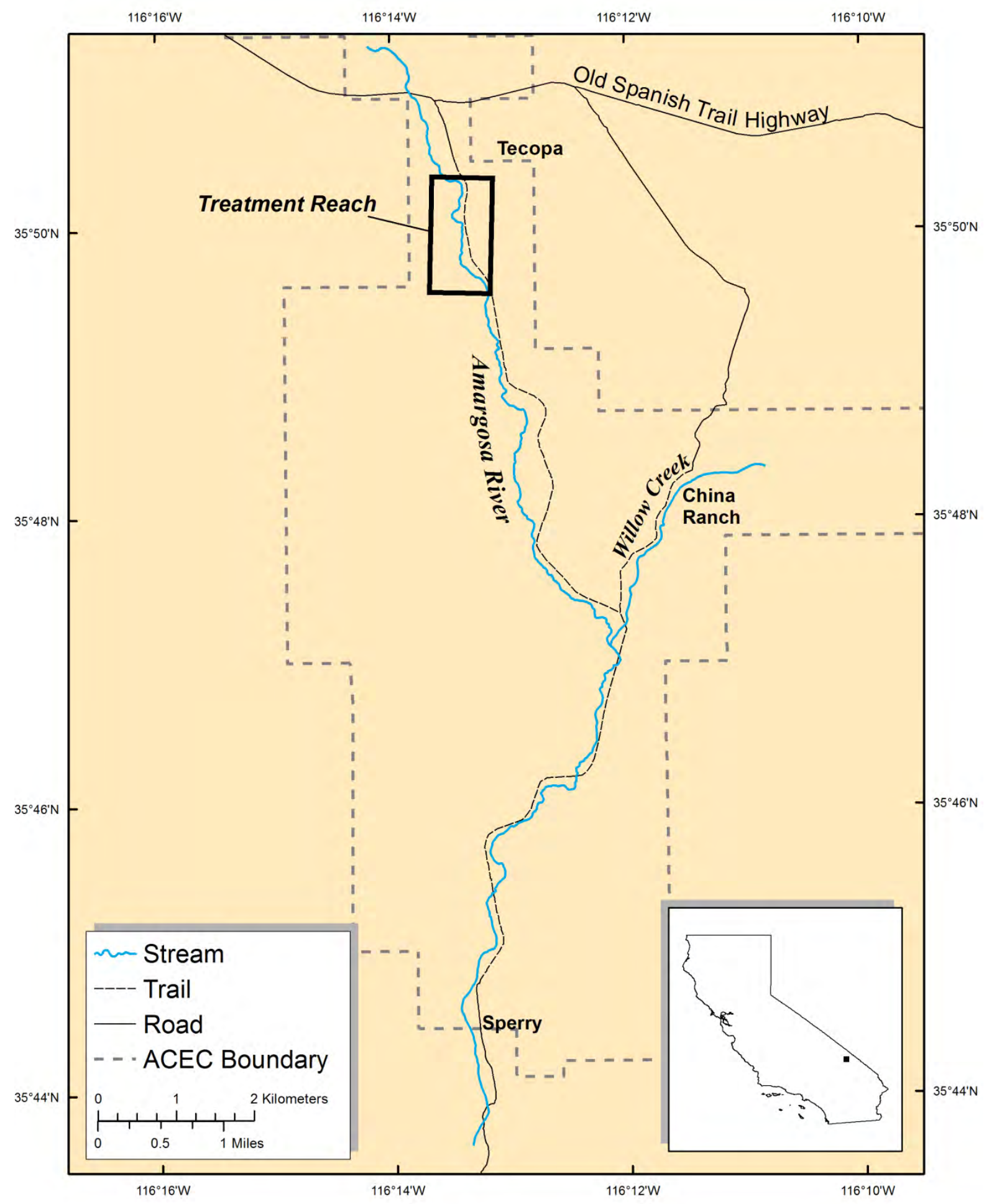

Figure 1. Map showing location of surveyed treatment reach on Amargosa River in Bureau of Land Management Area of Critical Environmental Concern (ACEC), southeastern California. 


\section{Methods}

Sampling for fishes in the treatment reach in 2010 occurred between June 21 and July 29, and sampling in 2014 occurred between October 6 and 8. The treatment reach begins 1.5 river kilometers downstream of the Old Spanish Trail Highway (OSTH) near the town of Tecopa, California, and ends 3.05 river kilometers downstream of OSTH. The total stream reach was 1.55 river kilometers in length (fig. 1). We used Geographic Information System (GIS) tools in ArcGISTM 10 (Environmental Systems Research Institute, 2010) and the National Agricultural Imagery Program (NAIP) to trace stream channels and to determine sampling locations. In 2010, there were 32 sample locations $50 \mathrm{~m}$ apart in the treatment reach. In 2014, the treatment reach was resampled at the same locations as in 2010; however, a 500-m section in the middle of the reach (beginning 2.05 river kilometers downstream of the OSTH) was sampled every $12.5 \mathrm{~m}$. A total of 62 locations were sampled in 2014 . Because of the different sample regimes conducted in 2014, the sampled reach was divided into three sections: (1) upper (total distance $550 \mathrm{~m}, 50 \mathrm{~m}$ apart, 11 locations in 2010 and 2014), (2) middle (total distance $500 \mathrm{~m}, 12.5 \mathrm{~m}$ apart in 2014, 11 locations in 2010 and 41 locations in 2014), and (3) lower (total distance $500 \mathrm{~m}, 50 \mathrm{~m}$ apart, 10 locations in 2010 and 2014). Standard Gee minnow traps with 3.3-mm mesh were baited with dry dog food and fished overnight (18-22 h) at each sampling location one time during each survey. Fish captured were identified to species and enumerated. Ten fish of each species (if available) per trap were measured to fork length (speckled dace) or total length (pupfish and mosquitofish). Red swamp crayfish also were enumerated and measured from the tip of the rostrum to the tip of the uropods. Fish and crayfish captured in traps were placed in a container with regional water until enumerated and measured and then returned to the stream in the location where they were captured. Stream depth, width, and temperature were recorded at each sample location in 2014. Dominant riparian vegetation type (native sedge/non-native Typha spp. or Phragmites australis) based on visual interpretation was recorded at each sample location. The 2014 survey of riparian vegetation type was more detailed in that it consisted of more categories and percentage of cover for two dominant riparian vegetation types.

\section{Results and Discussion}

Total number of pupfish captured in the treatment reach were similar in $2010(1,207)$ and 2014 (1,073); however, the catch per unit effort (CPUE, catch per trap), was much higher in 2010 (37.72) than in 2014 (17.31). Total number of speckled dace captured in the treatment reach were lower in 2010 (572) than in 2014 (960); however, the CPUE was higher in 2010 (17.88) than in 2014 (15.48). Mosquitofish captures were similar in 2010 (137) and 2014 (121) and CPUE was higher in 2010 (4.28) than in 2014 (1.95). Crayfish captures were lower in 2010 (73) than in 2014 (226), and CPUE was lower in 2010 (2.28) than in 2014 (3.65) (table 1).

During the 2010 survey, a total of 201 (female $=103$, male=98) pupfish were measured (total length), with a mean length of $45.6 \mathrm{~mm}$ (standard deviation [SD]=5.8). During the 2014 survey, a total of 270 (female $=175$, male $=85$, juvenile $=10$ ) pupfish were measured, with a mean length of $41.5 \mathrm{~mm}$ ( $\mathrm{SD}=7.4)$. Mean lengths of males (47.4 $\mathrm{mm}$ in 2010 and $46.6 \mathrm{~mm}$ in 2014) were larger than mean lengths of females (43.5 $\mathrm{mm}$ in 2010 and $40.3 \mathrm{~mm}$ in 2014). Length histograms of pupfish were similar in 2010 and 2014, with the exception that in 2014, 10 juveniles were measured ranging from 18 to 26 $\mathrm{mm}$ in length, most likely contributing to the differences in mean lengths between 2010 and 2014 (fig. 2). More juvenile pupfish were captured in the 2014 survey (taken in autumn) than in the 2010 survey (taken in summer), indicating that juveniles in this system do not reach trapping size until autumn. 
During the 2010 survey, a total of 215 speckled dace were measured (fork length), with a mean length of $53.4 \mathrm{~mm}(\mathrm{SD}=13.7)$. During the 2014 survey, a total of 395 speckled dace were measured, with a mean length of $47.7 \mathrm{~mm}(\mathrm{SD}=11.6)$. The length histograms of speckled dace differ between years; in 2014, there is a clear distinction between two groups of speckled dace (fig. 3). This distinction in lengths could be owing to different cohorts present in the population and (or) differences in lengths between males and females, which cannot be determined in the field. Mean length of crayfish was 62.4 $\mathrm{mm}(\mathrm{SD}=8.8, \mathrm{n}=73)$ in 2010 and $61.6 \mathrm{~mm}(\mathrm{SD}=14.0, \mathrm{n}=143)$ in 2014. Mean length (total length) of mosquitofish was $34.0 \mathrm{~mm}(\mathrm{SD}=8.9, \mathrm{n}=67)$ in 2010 and $30.7(\mathrm{SD}=6.2, \mathrm{n}=88)$ in 2014 .

Table 1. Total captures and catch per unit effort (CPUE) of fishes and crayfish in the treatment reach of the Amargosa River Canyon, California, surveyed in 2010 and 2014.

\begin{tabular}{llrr|rr}
\hline \multirow{2}{*}{ Reach } & \multicolumn{2}{c}{ Species } & \multicolumn{2}{c}{ Capture } & \multicolumn{2}{c}{ CPUE } \\
\cline { 3 - 6 } & 2010 & $\mathbf{2 0 1 4}$ & $\mathbf{2 0 1 0}$ & $\mathbf{2 0 1 4}$ \\
\hline \multirow{4}{*}{ Upper } & Pupfish & 68 & 11 & 6.18 & 1.00 \\
& Speckled dace & 344 & 383 & 31.27 & 34.82 \\
& Mosquitofish & 105 & 33 & 9.55 & 3.00 \\
& Crayfish & 35 & 104 & 3.18 & 9.45 \\
\hline \hline \multirow{4}{*}{ Middle } & Pupfish & 652 & 957 & 59.27 & 23.34 \\
& Speckled dace & 169 & 457 & 15.36 & 11.15 \\
& Mosquitofish & 24 & 79 & 2.18 & 1.93 \\
& Crayfish & 24 & 119 & 2.18 & 2.90 \\
\hline \hline \multirow{4}{*}{ Lower } & Pupfish & 487 & 105 & 48.70 & 10.50 \\
& Speckled dace & 59 & 120 & 5.90 & 12.00 \\
& Mosquitofish & 8 & 9 & 0.80 & 0.90 \\
& Crayfish & 14 & 3 & 1.40 & 0.30 \\
\hline \hline \multirow{6}{*}{ TOTAL } & Pupfish & 1,207 & 1,073 & 37.72 & 17.31 \\
& Speckled dace & 572 & 960 & 17.88 & 15.48 \\
& Mosquitofish & 137 & 121 & 4.28 & 1.95 \\
& Crayfish & 73 & 226 & 2.28 & 3.65 \\
& & & & & \\
\hline
\end{tabular}




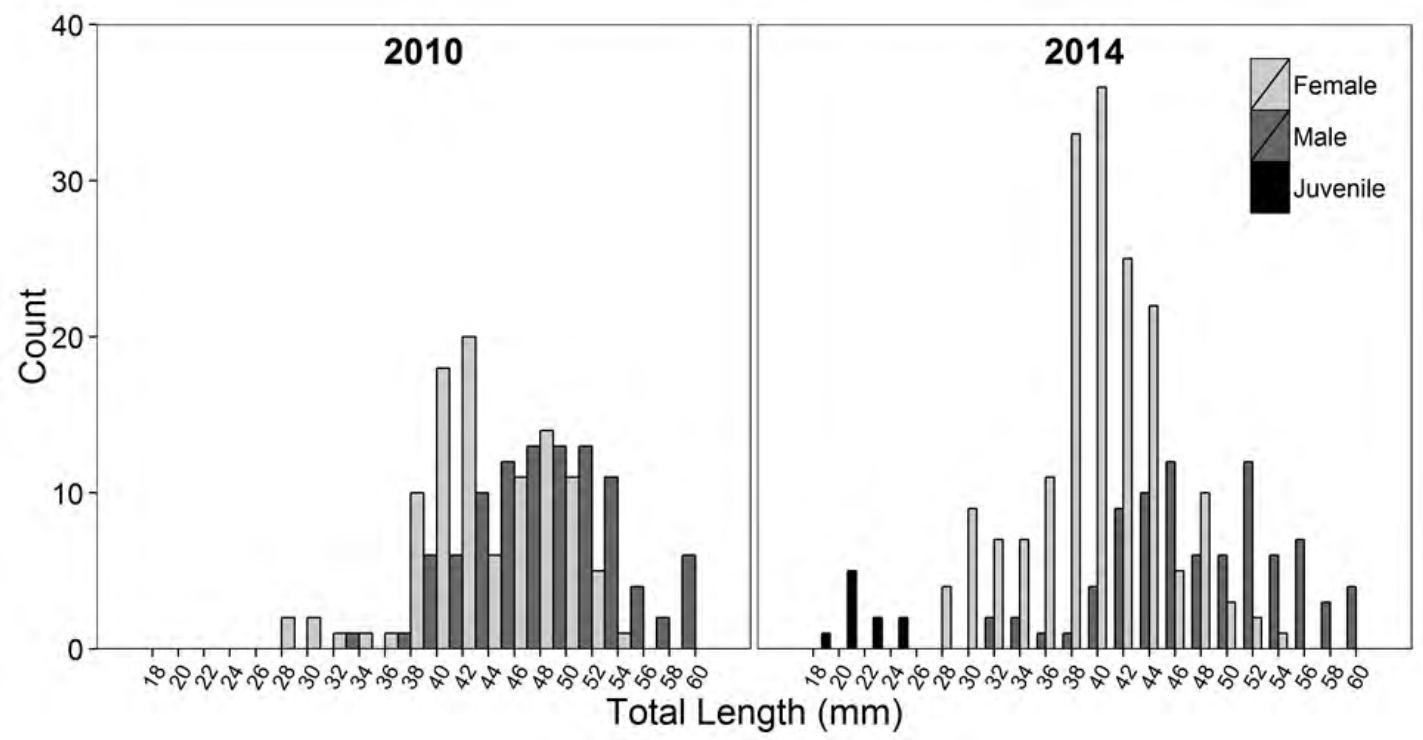

Figure 2. Length histograms (in millimeters [mm]) of Amargosa River pupfish (Cyprinodon nevadensis amargosae) captured in the treatment reach of the Amargosa River, California, during the 2010 and 2014 surveys. Sample size of pupfish measured (total length) was 201 (female=103, male=98) in 2010, and 270 (female=175, male=85, juvenile=10) in 2014.

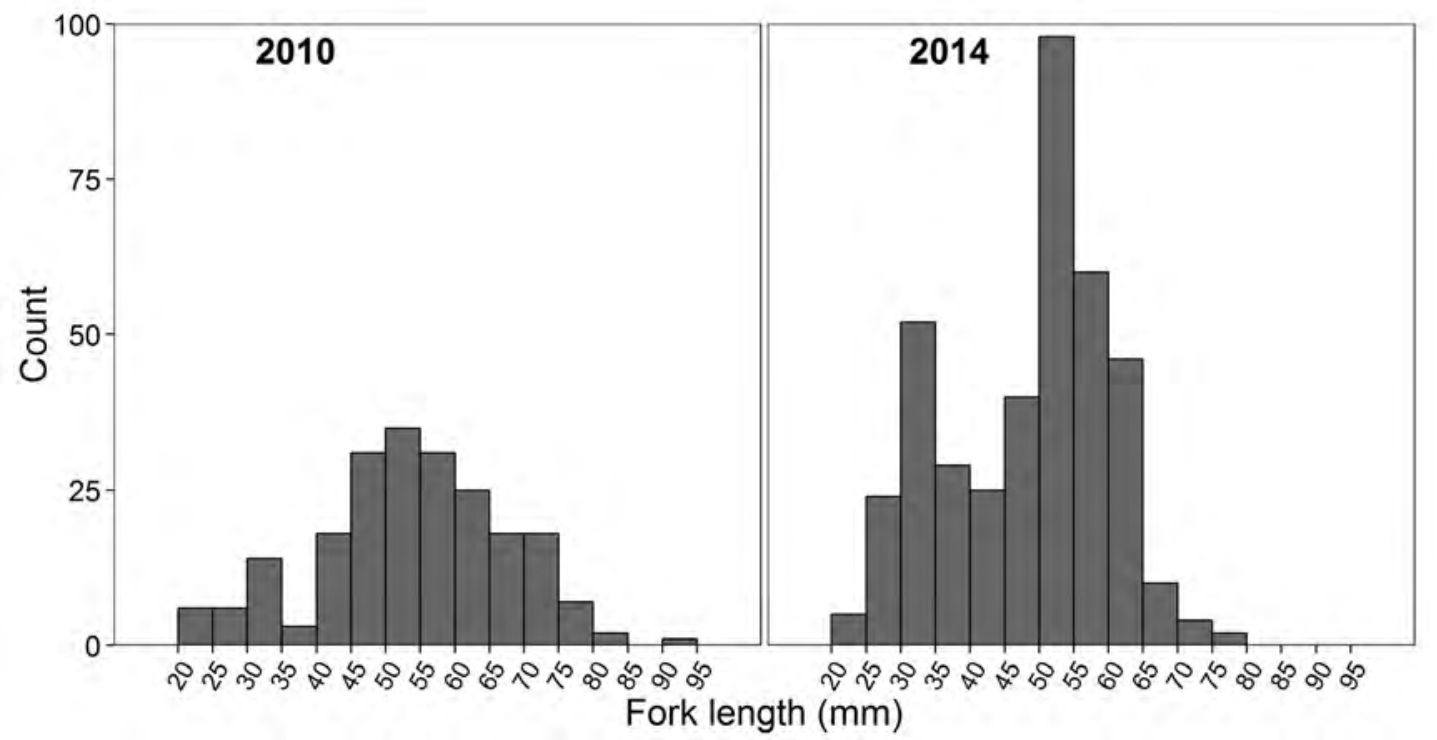

Figure 3. Length histograms (in millimeters [mm]) of speckled dace (Rhinichthys osculus spp.) captured in the treatment reach of the Amargosa River, California, during the 2010 and 2014 surveys. Sample size of speckled dace measured (fork length) was 215 in 2010 and 395 in 2014. 
The distribution of pupfish in 2010 and 2014 was similar in that most of the large captures occurred in the middle reach. In 2010 and 2014, the fewest captures occurred in the upper reach. However, pupfish captures (total and CPUE) were lower throughout the entire surveyed area in 2014 than in 2010, most notably in the upper and lower reaches (fig. 4). Speckled dace captures were higher in 2014 than in 2010 in the upper and lower reaches, but lower in the middle reach (fig. 5). Mosquitofish distribution was similar in both years, with the exception of the upper reach where captures were lower in 2014 (fig. 6). Crayfish captures increased in 2014 in the upper and middle reaches, most notably in the upper reach, and decreased in 2014 in the lower reach (fig. 7). Total captures and CPUE for each reach and year are shown in table 1.

In 2010, the riparian vegetation in the upper reach was dominated by cattail (Typha spp.) and common reed (Phragmites australis), whereas the middle and lower reaches were dominated by native sedges (fig. 8). The 2014 survey consisted of a more detailed survey with more riparian plant community descriptions; therefore, a complete comparison across years could not be conducted. However, the 2014 survey of riparian vegetation indicated that the middle reach was dominated by cattail, whereas the lower reach consisted mostly of sites dominated by sedge. Based on the 2014 survey, it appears that common reed is spreading throughout the entire study reach (fig. 8). A description of the percentage of riparian vegetation cover, stream width, stream depth, and temperature for each site is available in appendix A.

The decrease in pupfish captures in 2014 could be owing to a number of factors other than a change in abundance. The timing of sampling was different in 2010 and 2014 so observed differences in fish populations could be owing to seasonal changes in recruitment and (or) movement. Streamflows in the Amargosa River Canyon are consistent (average $2.21 \mathrm{ft}^{3} / \mathrm{s}$; U.S. Geological Survey, 1995) because they originate from springs associated with an alluvial aquifer in contact with bedrock. This system, however, is subject to flash flood events. The maximum instantaneous discharge was measured at 1,500 ft 3 /s in February 1969 (Anderson, 2005). A similar event occurred in December 2010 when stream discharge peaked at $1,050 \mathrm{ft}^{3} / \mathrm{s}$ on the Amargosa River downstream of the OSTH at U.S. Geological Survey streamgage 10251300 (U.S. Geological Survey, 2016). This flash flood occurred between the two surveys and could have affected the assemblage and abundance of fishes in the Amargosa River Canyon, resulting in the lower captures in the 2014 survey (Labbe and Fausch, 2000; Dexter and others, 2014; Bond and others, 2015). Changes in riparian vegetation could also contribute to changes in fish populations. The vegetation survey conducted in 2014 indicated that the middle reach was dominated by cattail and common reed, which have the potential to decrease streamflows creating habitat less suitable for species such as pupfish and speckled dace (Scoppettone and others, 2005). 


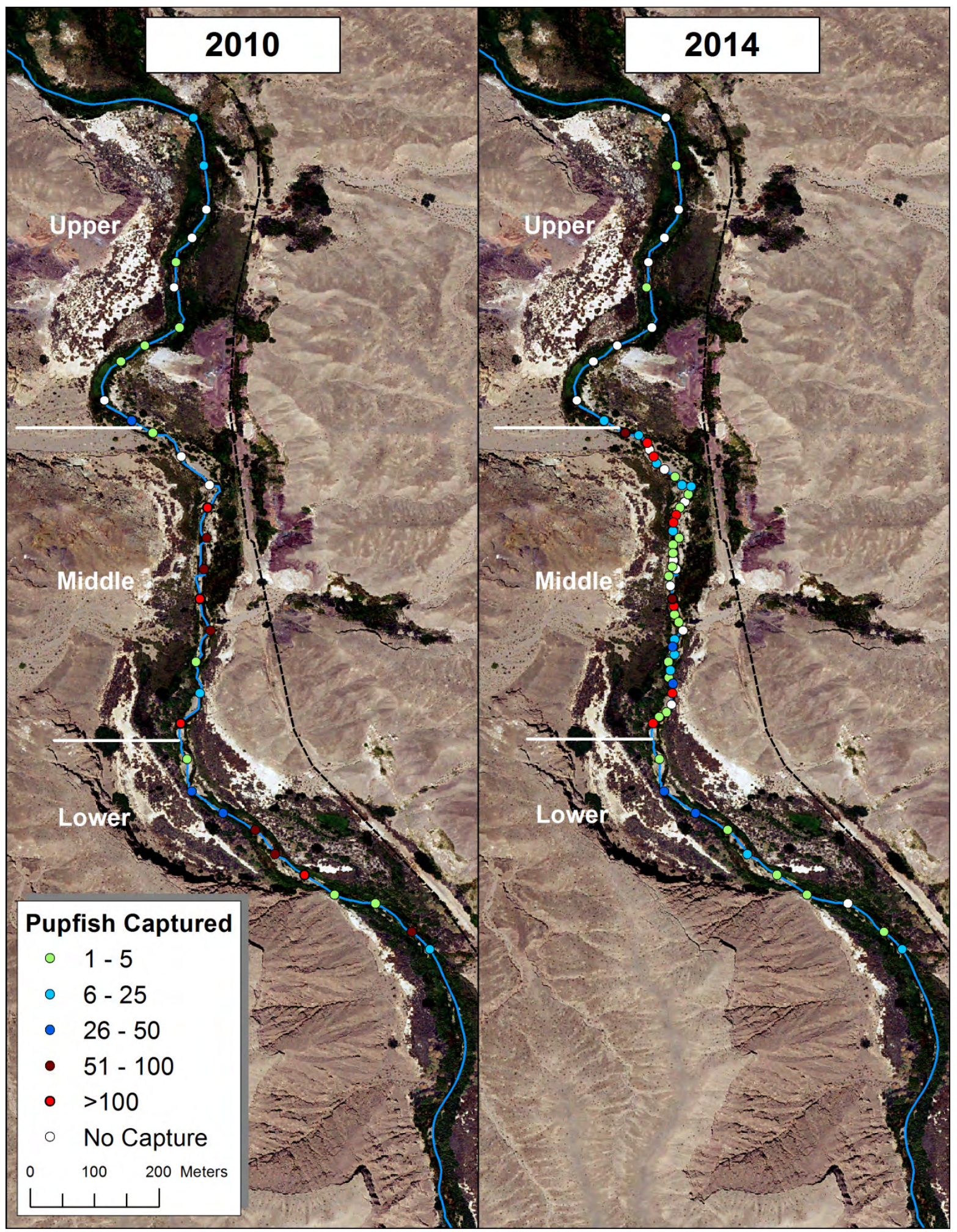

Figure 4. Relative distribution and abundance of Amargosa River pupfish (Cyprinodon nevadensis amargosae) along the treatment reach of the Amargosa River, California, surveyed in 2010 and 2014. Each dot represents an individual trap location. Base imagery from National Agriculture Imagery Program (NAIP), 2014. 


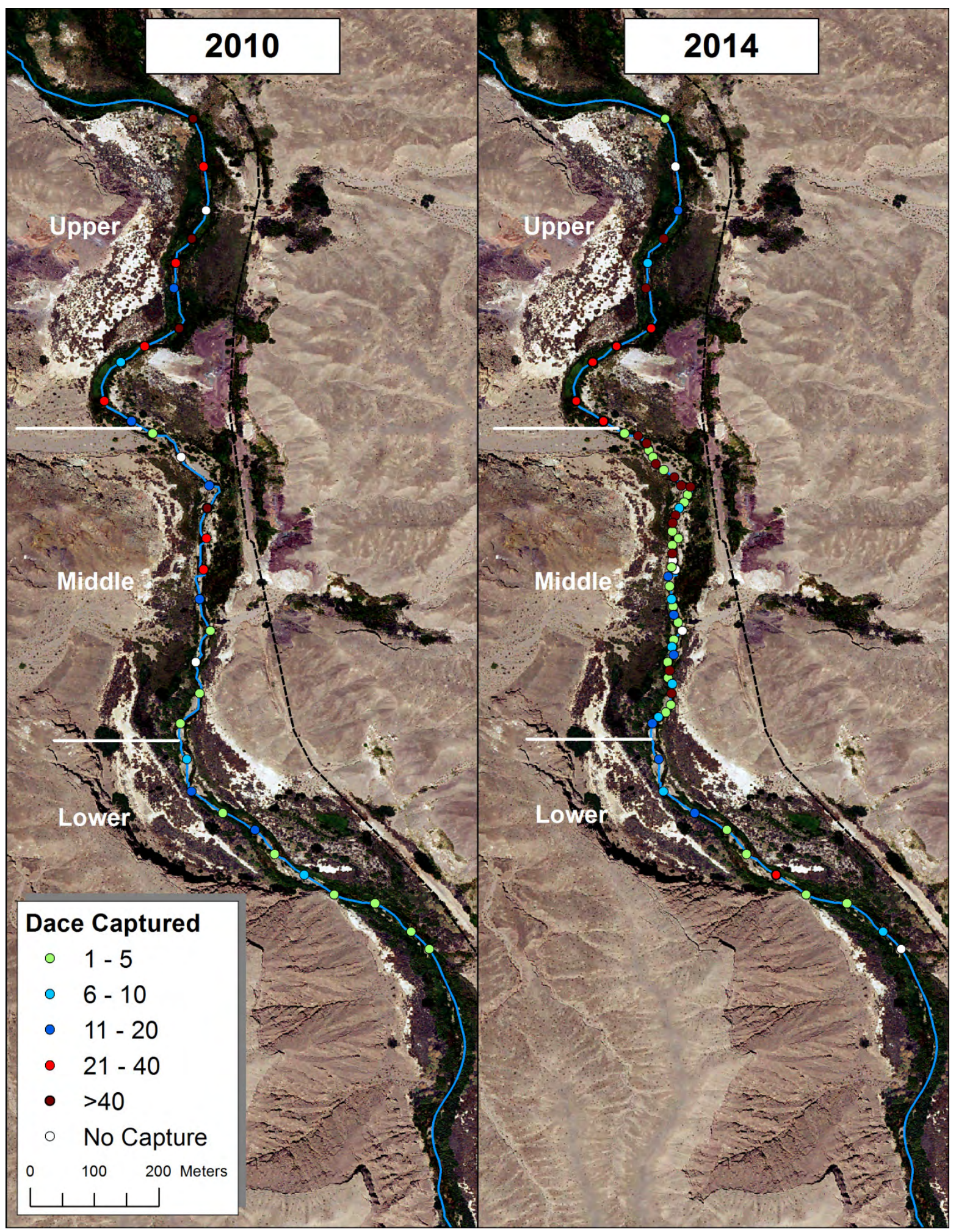

Figure 5. Relative distribution and abundance of speckled dace (Rhinichthys osculus spp.) along the treatment reach of the Amargosa River, California, surveyed in 2010 and 2014. Each dot represents an individual trap location. Base imagery from National Agriculture Imagery Program (NAIP), 2014. 


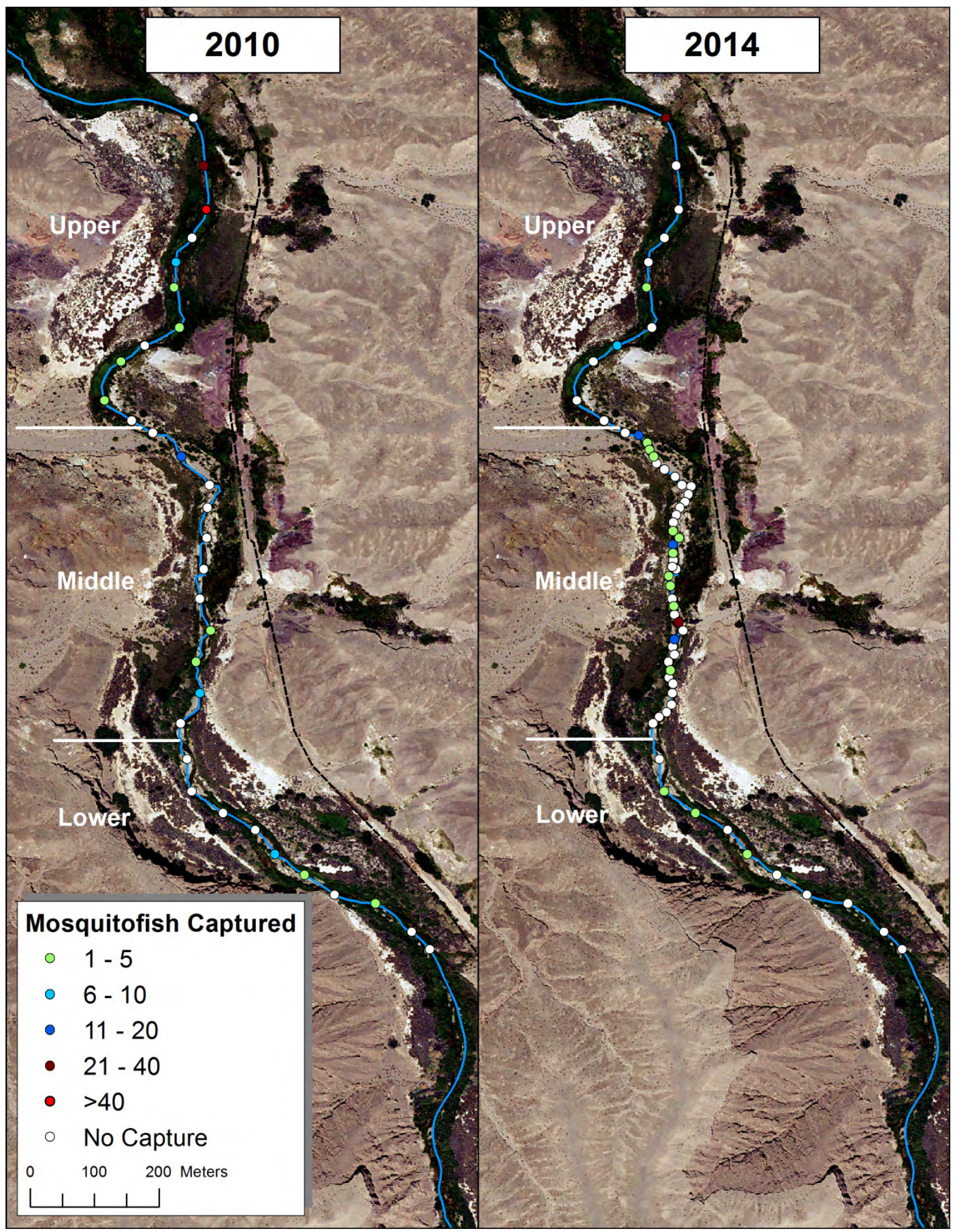

Figure 6. Relative distribution and abundance of western mosquitofish (Gambusia affinis) along the treatment reach of the Amargosa River, California, surveyed in 2010 and 2014. Each dot represents an individual trap location. Base imagery from National Agriculture Imagery Program (NAIP), 2014. 


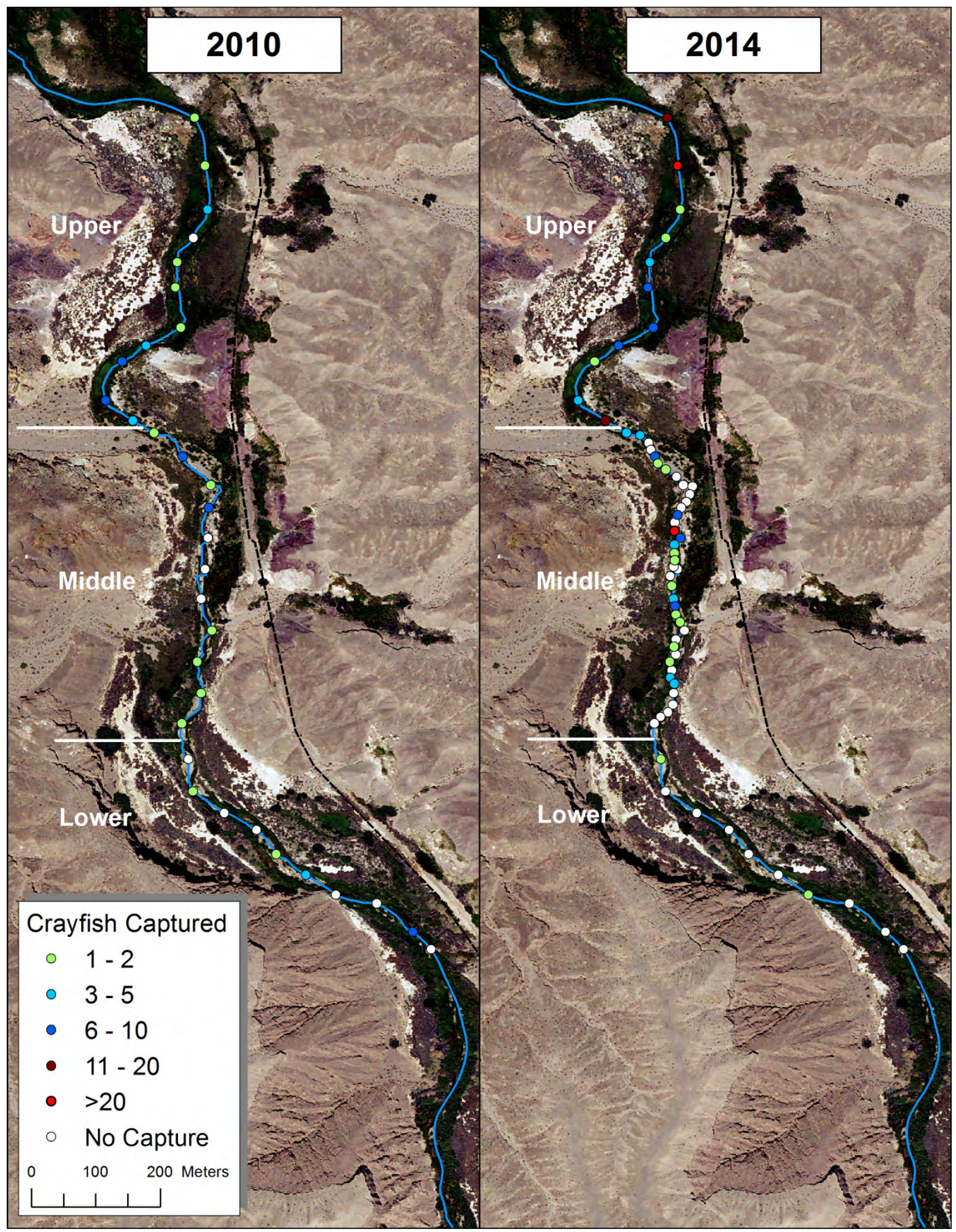

Figure 7. Relative distribution and abundance of red swamp crayfish (Procambarus clarkii) along the treatment reach of the Amargosa River, California, surveyed in 2010 and 2014. Each dot represents an individual trap location. Base imagery from National Agriculture Imagery Program (NAIP), 2014. 


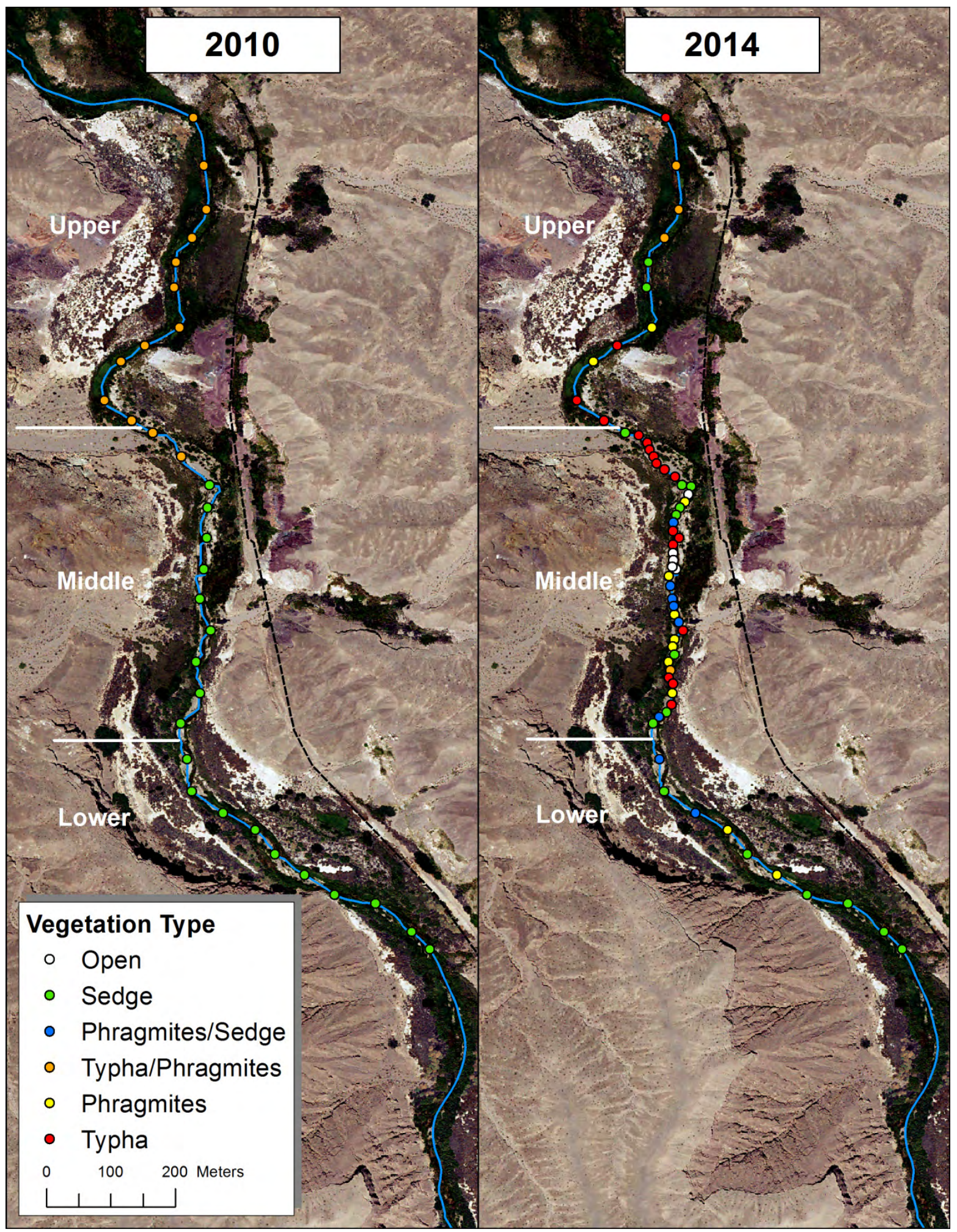

Figure 8. Dominant riparian vegetation present at sample sites during fish and crayfish surveys along the treatment reach of the Amargosa River, California, 2010 and 2014. Each dot represents an individual trap location. Base imagery from National Agriculture Imagery Program (NAIP), 2014. 


\section{Management Implications}

The decrease in pupfish CPUE from 2010 to 2014 in this surveyed reach is concerning, although this could be an artifact of seasonal variation or a natural response after a flash flood. A survey of this reach in the summer months could determine whether this decrease is seasonal or an actual decrease in pupfish abundance. Future monitoring efforts of fishes in the Amargosa River Canyon should be conducted in the same month to account for seasonal changes in abundance and distribution. A quantitative study design that does not rely on the assumption that capture probability remains constant over time and space could be more useful as more reaches of stream are treated for removal of saltcedar. Although the population of non-native mosquitofish does not appear to be increasing in this reach, the red swamp crayfish CPUE has increased. Although saltcedar is an invasive species of concern in the Amargosa River Canyon, restoration efforts should consider monitoring and removal of other aquatic invasive species such as cattail and common reed as a priority, as these species are becoming more prevalent and could negatively affect native fish species by decreasing stream velocities to favor nonnative species. Past fish surveys of the Amargosa River Canyon have indicated that red swamp crayfish occur in higher densities in areas dominated by saltcedar (Scoppettone and others, 2011). Kennedy and others (2005) showed that removal of saltcedar in a desert stream similar to the Amargosa River increased native fish abundance and decreased the abundance of crayfish. The 2010 and 2014 fish and crayfish surveys can be used as a baseline to determine the effects of saltcedar removal as a management strategy in the Amargosa River Canyon Area of Critical Environmental Concern to maintain and enhance the Amargosa River pupfish and speckled dace populations.

\section{Acknowledgments}

Data for this study were collected in 2014 by U.S. Geological Survey Western Fisheries Research Center, Reno, Nevada, field station staff Mark Fabes, Pete Rissler, with help from Eric Miskow of the Nevada Natural Heritage Program. Gary Scoppettone, Danielle Hereford, Antonio Salgado, Mark Fabes, and Pete Rissler of the U.S. Geological Survey Western Fisheries Research Center, Reno, Nevada Field station collected data in 2010.

\section{References Cited}

Allan, D.J., and Flecker, A.S., 1993, Biodiversity conservation in running waters: Bioscience, v. 43, p. 32-43.

Anderson, D.E., 2005, Holocene fluvial geomorphology of the Amargosa River through Amargosa Canyon, California: Earth-Science Reviews, v. 73, p. 291-307.

Bond, N.R., Balcombe, S.R., Crook, D.A., Marshall, J.C., Menke, N., and Lobegeiger, J.S., 2015, Fish population persistence in hydrologically variable landscapes: Ecological Applications, v. 25, p. 901913.

Bureau of Land Management, 2006, Amargosa River Area of Critical Environmental Concern Implementation Plan: Barstow, California, Bureau of Land Management Barstow Field Office, 285 p. Caiola, N., and de Sostoa, A., 2005, Possible reasons for the decline of two native toothcarps in the Iberian Peninsula-Evidence of competition with the introduced Eastern mosquitofish: Journal of Applied Ichthyology, v. 21, p. 358-363.

Deacon, J.E., and Deacon-Williams, C., 1991, Ash Meadows and the legacy of the Devils Hole pupfish, in Minckley, W.L., and Deacon, J.E., eds., Battle against extinction-Native fish management in the American West: Tucson, University of Arizona Press, p. 69-87. 
Dexter, T., Bond, N., Hale, R., and Reich, P., 2014, Dispersal and recruitment of fish in an intermittent stream network: Austral Ecology, v. 39, p. 225-235.

Di Tomaso, J.M., 1998, Impact, biology, and ecology of saltcedar (Tamarix spp.) in the Southwestern United States: Weed Technology, v. 12, p. 326-336.

Dudgeon, D., Arthington, A.H., Gessner, M.O., Kawabata, Z.I., Knowler, D.J., Leveque C., Naiman, R.J., Prieur-Richard, A.H., Soto, D., Stiassny, M.L.J., and Sullivan, C.A., 2006, Freshwater biodiversity-Importance, threats, status and conservation challenges: Biological Reviews, v. 81, p $163-182$.

Environmental Systems Research Institute, 2010, ArcGISTM, version 10: Environmental Systems Research Institute, Redlands, California.

Guan, R., and Wiles, P.R., 1997, Ecological impacts of introduced crayfish on benthic fishes in a British lowland river: Conservation Biology, v.11, p. 641-647.

Hubbs, C.L., and Miller, R.R., 1948, The Zoological evidence-Correlation between fish distribution and hydrographic history in the desert basins of Western United States, in The Great Basin, with emphasis on glacial and post glacial times: Bulletin of the University of Utah, Biological Series 10, v. 38 , no. 20, p. 17-166.

Kennedy, T.A., Finlay, J.C., and Hobbie, S.E., 2005, Eradication of invasive Tamarix ramosissma along a desert stream increases native fish diversity: Ecological Applications, v. 15, p. 2,072-2,083.

Kennedy, T.A., and Hobbie, S.E., 2004, Saltcedar (Tamarix ramosissima) invasion alters organic matter dynamics in a desert stream: Freshwater Biology, v. 49, p. 65-76.

Labbe, T.R., and Fausch, K.D., 2000, Dynamics of intermittent stream habitat regulate persistence of threatened fish at multiple scales: Ecological Applications, v. 10, p. 1,774-1,791.

Malmqvist, B., and Rundle, S., 2002, Threats to the running water ecosystems of the world: Environmental Conservation, v. 29, p. 134-153.

Scoppettone, G.G., Hereford, M.E., Rissler, P.H., Johnson, D.M., and Salgado, J.A., 2011, Relative abundance and distribution of fishes within an established Area of Critical Environmental Concern, of the Amargosa River Canyon and Willow Creek, Inyo and San Bernardino Counties, California: U.S. Geological Survey Open-File Report 2011-1161, 32 p.

Scoppettone, G.G., Rissler, P.H., Gourley, C., and Martinez, C., 2005, Habitat restoration as a means of controlling non-native fish in a Mojave Desert oasis: Restoration Ecology, v. 13, p. 247-256.

Shafroth, P.B., Cleverly, J.R., Dudley, T.L., Taylor, J.P., Van Riper, C., Weeks, E.P., and Stuart, J.N., 2005, Control of Tamarix in the Western United States-Implications for water salvage, wildlife use, and riparian restoration: Environmental Management, v. 35, p. 231-246.

Ward, J.V., 1998, Riverine landscapes-Biodiversity patterns, disturbance regimes, and aquatic conservation: Biological Conservation, v. 83, p. 269-278.

Williams, J.E., Kobetich, G.C., and Benz, C.T., 1984, Management aspects of relict populations inhabiting the Amargosa Canyon Ecosystem, in Warner, R.E., and Hendrix, K.M., eds., California riparian systems - Ecology, conservation, and productive management: Berkeley, University of California Press, p. 706-715.

U.S. Geological Survey, 1995, Water resources data Nevada Water Year 1994: U.S. Geological Survey Water Data Report NV-94-1.

U.S. Geological Survey, 2016, National Water Information System-Web interface (USGS water data for the Nation), accessed January 27, 2016, at http://waterdata.usgs.gov/ca/nwis/uv?site_no=10251300. 
Appendix A. Dominant Vegetation Type, Vegetation Percentage of Cover (2014 only), and Stream Characteristics (2014 only) from the 2010 and 2014 Fish and Crayfish Surveys of the Treatment Reach in the Amargosa River, California.

[Temp: temperature. Veg 1: first dominant vegetation. Veg 2: second dominant vegetation. Abbreviations: m, meter; mm, millimeter; na, not collected;

${ }^{\circ} \mathrm{C}$, degrees Celsius; -, zero observed]

\begin{tabular}{|c|c|c|c|c|c|c|c|c|c|c|c|c|}
\hline \multirow[b]{2}{*}{ Reach } & \multirow[b]{2}{*}{ Station } & \multirow[b]{2}{*}{ Latitude } & \multirow[b]{2}{*}{ Longitude } & \multicolumn{2}{|c|}{ Dominant vegetation type } & \multicolumn{4}{|c|}{2014 vegetation percentage of cover } & \multicolumn{3}{|c|}{$\begin{array}{c}2014 \text { stream } \\
\text { characteristics }\end{array}$} \\
\hline & & & & 2010 & 2014 & Veg 1 & Density 1 & Veg 2 & Density 2 & $\begin{array}{l}\text { Depth } \\
(\mathrm{mm})\end{array}$ & $\begin{array}{c}\text { Width } \\
(\mathrm{m})\end{array}$ & $\begin{array}{c}\text { Temp } \\
\left({ }^{\circ} \mathrm{C}\right)\end{array}$ \\
\hline Upper & AR01500 & 35.838806 & -116.223352 & Typha/Phragmites & Typha & Typha & 100 & - & - & 165 & 10 & 21.1 \\
\hline Upper & AR01550 & 35.838139 & -116.223207 & Typha/Phragmites & Typha/Phragmites & Typha & 50 & Phragmites & 50 & 300 & 10 & 21.7 \\
\hline Upper & AR01600 & 35.837524 & -116.223169 & Typha/Phragmites & Typha/Phragmites & Typha & 50 & Phragmites & 50 & 290 & 5 & 21.1 \\
\hline Upper & AR01650 & 35.837126 & -116.223373 & Typha/Phragmites & Typha/Phragmites & Typha & 50 & Phragmites & 50 & 330 & 5 & 21.1 \\
\hline Upper & AR01700 & 35.836786 & -116.223597 & Typha/Phragmites & Sedge & Sedge & 100 & - & - & 220 & 5 & 21.1 \\
\hline Upper & AR01750 & 35.836433 & -116.22362 & Typha/Phragmites & Sedge & Sedge & 100 & - & - & 195 & 5 & 21.1 \\
\hline Upper & AR01800 & 35.83587 & -116.223552 & Typha/Phragmites & Phragmites & Phragmites & 100 & - & - & 325 & 3 & 20.6 \\
\hline Upper & AR01850 & 35.835616 & -116.224032 & Typha/Phragmites & Typha & Typha & 90 & - & - & 570 & 5 & 20.0 \\
\hline Upper & AR01900 & 35.835393 & -116.22437 & Typha/Phragmites & Phragmites & Phragmites & 100 & - & - & 315 & 3 & 20.6 \\
\hline Upper & AR01950 & 35.83485 & -116.224598 & Typha/Phragmites & Typha & Typha & 100 & - & - & 330 & 10 & 21.1 \\
\hline Upper & AR02000 & 35.834571 & -116.224219 & Typha/Phragmites & Typha & Typha & 50 & - & - & 295 & 2.2 & 20.6 \\
\hline Middle & AR02050 & 35.834401 & -116.223924 & Typha/Phragmites & Sedge & Sedge & 5 & - & - & 330 & 2.5 & 20.0 \\
\hline Middle & AR02063 & 35.834363 & -116.223732 & na & Typha & Typha & 25 & - & - & 175 & 3.4 & 20.0 \\
\hline Middle & AR02075 & 35.834259 & -116.223611 & na & Typha & Typha & 50 & - & - & 470 & 2.6 & 20.0 \\
\hline Middle & AR02088 & 35.834161 & -116.223584 & na & Typha & Typha & 50 & - & - & 245 & 4.1 & 20.0 \\
\hline Middle & AR02100 & 35.834069 & -116.223522 & Typha/Phragmites & Typha & Typha & 5 & - & - & 430 & 4.7 & 20.6 \\
\hline Middle & AR02113 & 35.833968 & -116.223482 & na & Typha & Typha & 5 & - & - & 185 & 2.2 & 20.6 \\
\hline Middle & AR02125 & 35.833887 & -116.223375 & na & Typha & Typha & 10 & - & - & 160 & 2.2 & 20.6 \\
\hline Middle & AR02138 & 35.833782 & -116.223226 & na & Typha & Typha & 5 & - & - & 205 & 2 & 20.6 \\
\hline Middle & AR02150 & 35.833667 & -116.223131 & Sedge & Sedge & Sedge & 5 & - & - & 245 & 2.1 & 20.6 \\
\hline Middle & AR02163 & 35.833645 & -116.222998 & na & Sedge & Sedge & 15 & - & - & 375 & 2.2 & 21.1 \\
\hline
\end{tabular}




\begin{tabular}{|c|c|c|c|c|c|c|c|c|c|c|c|c|}
\hline \multirow[b]{2}{*}{ Reach } & \multirow[b]{2}{*}{ Station } & \multirow[b]{2}{*}{ Latitude } & \multirow[b]{2}{*}{ Longitude } & \multicolumn{2}{|c|}{ Dominant vegetation type } & \multicolumn{4}{|c|}{2014 vegetation percentage of cover } & \multicolumn{3}{|c|}{$\begin{array}{c}2014 \text { stream } \\
\text { characteristics }\end{array}$} \\
\hline & & & & 2010 & 2014 & Veg 1 & Density 1 & Veg 2 & Density 2 & $\begin{array}{l}\text { Depth } \\
(\mathrm{mm})\end{array}$ & $\begin{array}{l}\text { Width } \\
(\mathrm{m})\end{array}$ & $\begin{array}{l}\text { Temp } \\
\left({ }^{\circ} \mathrm{C}\right)\end{array}$ \\
\hline Middle & AR02175 & 35.833538 & -116.223035 & na & Open & Open & 0 & - & - & 280 & 3.1 & 21.1 \\
\hline Middle & AR02188 & 35.83343 & -116.223091 & na & Phragmites & Phragmites & 2 & - & - & 175 & 3.3 & 21.1 \\
\hline Middle & AR02200 & 35.833354 & -116.223155 & Sedge & Sedge & Sedge & 75 & - & - & 300 & 2.6 & 20.6 \\
\hline Middle & AR02213 & 35.833251 & -116.223205 & na & Sedge & Sedge & 50 & - & - & 390 & 3.9 & 20.6 \\
\hline Middle & AR02225 & 35.833147 & -116.223251 & na & Phragmites/Sedge & Phragmites & 10 & Sedge & 10 & 235 & 2.4 & 21.7 \\
\hline Middle & AR02238 & 35.833026 & -116.223254 & na & Typha & Typha & 5 & - & - & 250 & 4.8 & 21.1 \\
\hline Middle & AR02250 & 35.832929 & -116.223165 & Sedge & Typha & Typha & 15 & - & - & 250 & 5.2 & 21.1 \\
\hline Middle & AR02263 & 35.832832 & -116.223253 & na & Typha & Typha & 2 & - & - & 170 & 3.9 & 21.1 \\
\hline Middle & AR02275 & 35.832715 & -116.223256 & na & Open & Open & 0 & - & - & 160 & 3.8 & 21.1 \\
\hline Middle & AR02288 & 35.832616 & -116.223248 & na & Open & Open & 0 & - & - & 145 & 3.4 & 21.7 \\
\hline Middle & AR02300 & 35.832489 & -116.223206 & Sedge & Open & Open & 0 & - & - & 140 & 5.7 & 21.7 \\
\hline Middle & AR02313 & 35.832521 & -116.223267 & na & Open & Open & 0 & - & - & 150 & 2.2 & 21.7 \\
\hline Middle & AR02325 & 35.832393 & -116.223312 & na & Phragmites & Phragmites & 20 & - & - & 40 & 2.4 & 21.7 \\
\hline Middle & AR02338 & 35.83226 & -116.223289 & na & Phragmites/Sedge & Phragmites & 25 & Sedge & 25 & 145 & 3.1 & 21.7 \\
\hline Middle & AR02350 & 35.832077 & -116.223264 & Sedge & Phragmites/Sedge & Phragmites & 10 & Sedge & 10 & 195 & 4.2 & 21.1 \\
\hline Middle & AR02363 & 35.831973 & -116.223246 & na & Phragmites/Sedge & Phragmites & 75 & Sedge & 75 & 310 & 3.6 & 21.7 \\
\hline Middle & AR02375 & 35.831852 & -116.223236 & na & Phragmites & Phragmites & 10 & - & - & 250 & 2 & 21.7 \\
\hline Middle & AR02388 & 35.831749 & -116.22317 & na & Phragmites/Sedge & Phragmites & 15 & Sedge & 15 & 155 & 3.9 & 22.2 \\
\hline Middle & AR02400 & 35.831633 & -116.223114 & Sedge & Typha & Typha & 5 & - & - & 140 & 3.7 & 22.2 \\
\hline Middle & AR02413 & 35.831507 & -116.223234 & na & Phragmites & Phragmites & 10 & - & - & 145 & 1.9 & 21.7 \\
\hline Middle & AR02425 & 35.831406 & -116.223258 & na & Phragmites & Phragmites & 15 & - & - & 210 & 2.9 & 21.7 \\
\hline Middle & AR02438 & 35.831294 & -116.223233 & na & Sedge & Sedge & 90 & - & - & 200 & 3.6 & 21.1 \\
\hline Middle & AR02450 & 35.831196 & -116.223315 & Sedge & Phragmites & Phragmites & 25 & - & - & 145 & 3.5 & 21.7 \\
\hline Middle & AR02463 & 35.831074 & -116.22329 & na & Typha/Phragmites & Typha & 25 & Phragmites & 25 & 255 & 3.8 & 21.7 \\
\hline Middle & AR02475 & 35.830973 & -116.223313 & na & Typha & Typha & 20 & - & - & 175 & 5.7 & 21.7 \\
\hline Middle & AR02488 & 35.830888 & -116.223255 & na & Typha & Typha & 50 & - & - & 475 & 2.8 & 22.2 \\
\hline Middle & AR02500 & 35.830753 & -116.223266 & Sedge & Phragmites & Phragmites & 5 & - & - & 250 & 5.7 & 21.1 \\
\hline Middle & AR02513 & 35.830594 & -116.223275 & na & Typha & Typha & 30 & - & - & 185 & 2.2 & 21.7 \\
\hline Middle & AR02525 & 35.83049 & -116.223342 & na & Sedge & Sedge & 50 & - & - & 190 & 3.3 & 22.2 \\
\hline
\end{tabular}




\begin{tabular}{|c|c|c|c|c|c|c|c|c|c|c|c|c|}
\hline \multirow[b]{2}{*}{ Reach } & \multirow[b]{2}{*}{ Station } & \multirow[b]{2}{*}{ Latitude } & \multirow[b]{2}{*}{ Longitude } & \multicolumn{2}{|c|}{ Dominant vegetation type } & \multicolumn{4}{|c|}{2014 vegetation percentage of cover } & \multicolumn{3}{|c|}{$\begin{array}{c}2014 \text { stream } \\
\text { characteristics }\end{array}$} \\
\hline & & & & 2010 & 2014 & Veg 1 & Density 1 & Veg 2 & Density 2 & $\begin{array}{l}\text { Depth } \\
(\mathrm{mm})\end{array}$ & $\begin{array}{l}\text { Width } \\
\text { (m) }\end{array}$ & $\begin{array}{c}\text { Temp } \\
\left({ }^{\circ} \mathrm{C}\right) \\
\end{array}$ \\
\hline Middle & AR02550 & 35.830335 & -116.223534 & Sedge & Sedge & Sedge & 50 & - & - & 395 & 2.7 & 21.7 \\
\hline Lower & AR02600 & 35.829833 & -116.22344 & Sedge & Phragmites/Sedge & Phragmites & 50 & Sedge & 50 & 340 & 2.4 & 21.7 \\
\hline Lower & AR02650 & 35.82938 & -116.223378 & Sedge & Sedge & Sedge & 15 & - & - & 215 & 4.6 & 21.1 \\
\hline Lower & AR02700 & 35.829081 & -116.222939 & Sedge & Phragmites/Sedge & Sedge & 15 & Phragmites & 15 & 335 & 4.7 & 21.1 \\
\hline Lower & AR02750 & 35.828843 & -116.222487 & Sedge & Phragmites & Phragmites & 10 & - & - & 130 & 4.8 & 21.1 \\
\hline Lower & AR02800 & 35.828506 & -116.222212 & Sedge & Sedge & Sedge & 15 & - & - & 150 & 5 & 21.1 \\
\hline Lower & AR02850 & 35.828213 & -116.221797 & Sedge & Phragmites & Phragmites & 90 & - & - & 320 & 1.8 & 20.0 \\
\hline Lower & AR02900 & 35.827933 & -116.221378 & Sedge & Sedge & Sedge & 90 & - & - & 168 & 1.7 & 20.0 \\
\hline Lower & AR02950 & 35.827814 & -116.220805 & Sedge & Sedge & Sedge & 100 & - & - & 148 & 2.3 & 18.9 \\
\hline Lower & AR03000 & 35.827416 & -116.2203 & Sedge & Sedge & Sedge & 90 & - & - & 152 & 4.3 & 18.9 \\
\hline Lower & AR03050 & 35.827172 & -116.220044 & Sedge & Sedge & Sedge & 30 & - & - & 140 & 1.7 & 18.3 \\
\hline
\end{tabular}


Publishing support provided by the U.S. Geological Survey

Science Publishing Network, Tacoma Publishing Service Center

For more information concerning the research in this report, contact the Director, Western Fisheries Research Center U.S. Geological Survey

6505 NE 65th Street

Seattle, Washington 98115

http://wfrc.usgs.gov/ 
